\title{
ABL2 wt Allele
}

National Cancer Institute

\section{Source}

National Cancer Institute. ABL2 wt Allele. NCI Thesaurus. Code C51062.

Human ABL2 wild-type allele is located within $1 \mathrm{q} 24-\mathrm{q} 25$ and is approximately $126 \mathrm{~kb}$ in length. This allele, which encodes tyrosine-protein kinase ABL2 protein, is involved in signal transduction. The ABL2 gene is translocated in acute myelogenous leukemia. 